\title{
TAGUCHI METHOD OPTIMIZATION OF OPERATING PARAMETERS FOR AUTOMOTIVE DISC BRAKE PAD WEAR
}

UDC: $629.3 .027 .484: 539.621$

Original scientific paper

https://doi.org/10.18485/aeletters.2021.6.2.1

\author{
Vaibhav A. Kalhapure ${ }^{1 *}$, H.P. Khairnar ${ }^{1}$ \\ ${ }^{1}$ Department of Mechanical Engineering, VJTI, Mumbai, India
}

\begin{abstract}
:
The friction pair, disc, and pad in a braking system are in a delicate balance, with the pad being a complex combination of constituents that provides predictable characteristics, including a known and consistent friction level. In this investigation, L25 orthogonal array with arranged control factors is used for the design of experiment. Taguchi design, orthogonal array, $\mathrm{S} / \mathrm{N}$ ratio and variance analysis (ANOVA) are used to explore the effect of factors like applied load, sliding speed and track or interface diameter on wear rate of brake pad friction material. In dry sliding conditions, wear tests are performed on the pin-on-disc tribometer with different load values (25-125 $\mathrm{N})$, sliding speeds (300-1500 rpm) and track diameter values $(40-120 \mathrm{~mm})$. ANOVA results stated that applied load is the most effective with $48.27 \%$, track diameter is $25 \%$ and sliding speed is $19.23 \%$ on wear rate of pad friction material. In order to obtain the minimum friction material wear rate, the optimum operating parameters have been identified as applied load is $25 \mathrm{~N}$, sliding speed $1500 \mathrm{rpm}$ and track diameter $60 \mathrm{~mm}$. The computed and experimental values for pad material wear rate are adhere closer to $1.93 \%$ of deviations only.
\end{abstract}

ARTICLE HISTORY Received: 22.03.2021. Accepted: 12.04.2021. Available: 30.06.2021.

\section{INTRODUCTION}

Brake pads of an automotive braking system are among the most complex composite materials because they contain a variety of ingredients with varying physical and chemical properties. Metallic ingredients are commonly used in friction materials for automotive braking systems to increase thermal diffusivity, wear resistance and strength. Friction and wear are extremely important in brake pad materials, the features of friction materials are extremely difficult to predict and they have a significant impact on brake system performance [13]. The brake pad is continuously worn and sacrificed during its short lifespan to keep the rotor in good working condition and the wear is a result of sliding friction among the brake pad and the rotor [4]. Several studies have shown the coefficient of friction and system wear are influenced by the characteristics of the friction layer formation at the pad-disc contact interface, which is affected by the compositions and properties of the contact materials $[5,6]$. Friction material degradation at high temperatures is a major problem, primarily due to the thermal decomposition of phenolic resins, which are commonly used as friction material binders $[7,8]$. In automobile brake components, asbestos free friction materials are in high demand. The friction and wear behaviour are complicated by the braking conditions. With high temperature, braking pressure and initial speed, the wear rate increases significantly [9-12]. A pad-ondisc test rig was used to perform the friction test. When commercial friction materials are used, the results from a simplified formulation with the use of a pad-on-disc test often show distinct friction properties than the results of dynamometer tests or in-vehicle testing [13-15]. A sensitivity analysis can be used to investigate various parameters and their influence on desired values and braking 
performance in greater detail with help of Taguchi and variance analysis (ANOVA) techniques. Previous works have used the Taguchi method to optimise the wear characteristics of various materials using various experiments. The Taguchi technique can also be used to achieve the best design levels [1620].

The majority of the present literature focuses on experimental findings based on brake pad wear performance and very few literature studies presented for the optimization of material removal rate of the brake pad in wear process. The presented investigate the effects of operating parameters on wear rate of brake pad were evaluated. Signal to noise ratio and analysis of variance (ANOVA) studies were carried out to determine important parameters influencing wear rate. The optimal operating parameters and their levels were computed using the $\mathrm{S} / \mathrm{N}$ ratio. In addition, using a wear rate equation, the measured values were predicted. Finally, confirmation experiments were used to test the developed model reliability.

\section{EXPERIMENTAL INVESTIGATION}

The Taguchi technique is used to find the optimum operating parameters in this experimental study. The orthogonal array $(O A)$ is a technique for checking performance characteristics with the least amount of trial. The experiments are carried out using an orthogonal array, and the results are then converted into a signal to noise ratio $(\mathrm{S} / \mathrm{N})$ in order to perform a characteristic analysis. The parameter design is carried to get optimum combinations. The methodological flow chart for Taguchi and ANOVA is shown in Fig. 1.

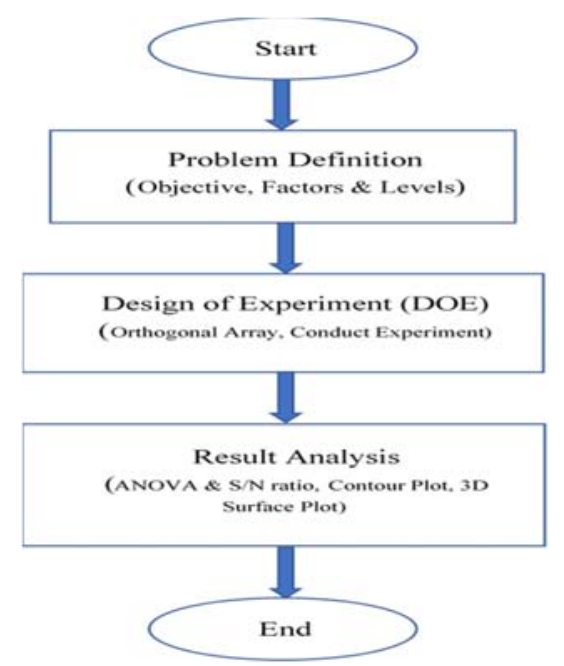

Fig. 1. Methodology Flow Chart

\subsection{Material and wear test}

Non-asbestos organic type friction materials containing various ingredients were investigated in this study. Total 25 pin samples of pad friction material were prepared as per ASTM G-99 test standards of size $30 \mathrm{~mm} \times 12 \mathrm{~mm}$ shown in Fig. 2 (a). The pins were cylindrical in shape and machined from pad friction material. The friction materials of brake pads were attached to mild steel pin with help of strong epoxy adhesive. The cast iron disc was casted with expendable mould in dry sand casting of dimension of $162 \mathrm{~mm} \times 8 \mathrm{~mm}$ produced in the present work as shown in Fig. 2 (b). The tests were conducted on a pin-on-disc machine with a horizontal rotating disc, using dead weight to exert the required nominal pin contact pressure as shown in Fig. 2 (c). The flat surface of the pin is essential for performing pin on the disc test, so that it is in conformity with the contact between disc surface. Dry sliding tests were performed with sliding speeds between $300 \mathrm{rpm}-1,500 \mathrm{rpm}$, nominal contact loads varied from $25 \mathrm{~N}-125 \mathrm{~N}$ and interface or track diameter from $40 \mathrm{~mm}-120 \mathrm{~mm}$ at constant sliding distance of $1000 \mathrm{~m}$. At the sliding interface, the friction force and vertical displacement of the pin were automatically measured in the pin-on-disc machine using a strain gauge and a linear variable differential transformer (LVDT). A controller and a computer were connected to the machine to control, monitor and measure sliding speed, time, frictional force and wear. With the help of WINDUCOM 2010 software, the friction coefficient (COF) and wear were continuously measured and recorded during the entire test. For the friction material, the wear rate $(\mathrm{m} / \mathrm{s})$ is determined by relation:

$$
\text { Wear Rate }(\mathrm{V})=\frac{\Delta W}{t}
$$

Where is: $\Delta W=$ wear amount of friction material and $\mathrm{t}=$ time required for wear.

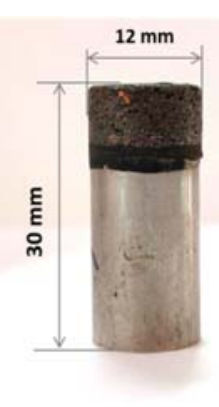

Fig. 2 a) Specimen dimensions

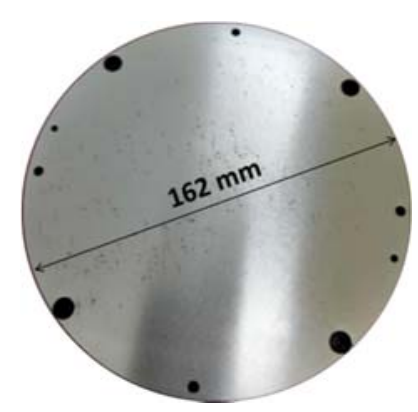

Fig. 2 b) Cast iron disc dimensions 


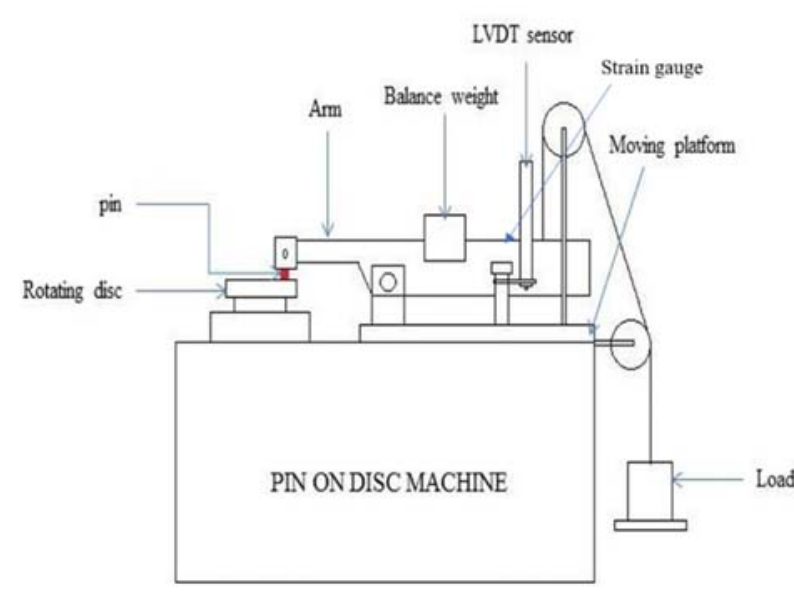

Fig. 2 c) Schematic of pin on disc test rig

\subsection{Test conditions and experimental design}

The experiments were designed to investigate the impact of various operating parameters on brake pad wear. Table 1 contains number and levels of the control factors. In engineering analysis and optimization, the Taguchi design is widely accepted and utilised. The number of experiments in Taguchi methods was reduced by using an orthogonal array, which also reduced the effects of uncontrollable factors. The Taguchi design's quality is ensured during the design phase. The Taguchi approach is used to minimise the number of trials, reduce experimental time, and lower production costs. Its main advantages are simplicity and accuracy. This was often used to identify the key factors in a short period of time. The loss function was evaluated using the Taguchi method. The experimental design had five levels, as shown in Table 1 L25 (243) was chosen as a standard Taguchi experimental plan. Table 2 shows an L25 orthogonal array with arranged control factors and contains the experimental strategy and findings, as well as the computed $\mathrm{S} / \mathrm{N}$ ratios for brake pad wear rate. The results of the measured wear rate and the calculated $\mathrm{S} / \mathrm{N}$ ratio were shown on the right side of the table. The following equation is used to compute the $\mathrm{S} / \mathrm{N}$ ratio:

$$
\frac{S}{N}=-10 \log \frac{1}{n}\left(\sum y^{2}\right)
$$

Where, $\mathrm{y}$ is the observed data and $\mathrm{n}$ is the number of observations. The $\mathrm{S} / \mathrm{N}$ ratio is calculated using the above equation, which is related to the smaller-is-better quality characteristics. In our case, the wear rate is a quality criterion where the lower the number, the better.
Table 1. Number and levels of control factors

\begin{tabular}{|l|c|c|c|c|c|c|}
\hline \multirow{2}{*}{$\begin{array}{l}\text { Control } \\
\text { Factors }\end{array}$} & \multicolumn{5}{|c|}{ Levels } & \multirow{2}{*}{ Units } \\
\cline { 2 - 6 } & $\mathrm{I}$ & $\mathrm{II}$ & $\mathrm{III}$ & $\mathrm{IV}$ & $\mathrm{V}$ & \\
\hline $\begin{array}{l}\text { Applied } \\
\text { Load }\end{array}$ & 25 & 50 & 75 & 100 & 125 & $\mathrm{~N}$ \\
\hline $\begin{array}{l}\text { Sliding } \\
\text { Speed }\end{array}$ & 300 & 600 & 900 & 1200 & 1500 & $\mathrm{rpm}$ \\
\hline $\begin{array}{l}\text { Track } \\
\text { Diameter }\end{array}$ & 40 & 60 & 80 & 100 & 120 & $\mathrm{~mm}$ \\
\hline
\end{tabular}

Table 2. L25 orthogonal array with control factors

\begin{tabular}{|l|c|c|c|c|c|}
\hline $\begin{array}{c}\text { Sr. } \\
\text { No. }\end{array}$ & $\begin{array}{c}\text { Applied } \\
\text { Load } \\
(\mathrm{N})\end{array}$ & $\begin{array}{c}\text { Sliding } \\
\text { Speed } \\
(\mathrm{rpm})\end{array}$ & $\begin{array}{c}\text { Track } \\
\text { Dia- } \\
\text { meter } \\
(\mathrm{mm})\end{array}$ & $\begin{array}{c}\text { Wear Rate } \\
(\mathrm{m} / \mathrm{s})\end{array}$ & $\begin{array}{c}\text { S/N } \\
\text { Ratio } \\
(\mathrm{dB})\end{array}$ \\
\hline 1. & 25 & 300 & 40 & $1.177 \cdot 10^{-08}$ & 158.584 \\
\hline 2. & 25 & 600 & 60 & $9.263 \cdot 10^{-09}$ & 160.665 \\
\hline 3. & 25 & 900 & 80 & $6.755 \cdot 10^{-09}$ & 163.407 \\
\hline 4. & 25 & 1200 & 100 & $1.514 \cdot 10^{-08}$ & 156.392 \\
\hline 5. & 25 & 1500 & 120 & $1.108 \cdot 10^{-08}$ & 159.106 \\
\hline 6. & 50 & 300 & 60 & $2.761 \cdot 10^{-08}$ & 151.176 \\
\hline 7. & 50 & 600 & 80 & $1.353 \cdot 10^{-08}$ & 157.374 \\
\hline 8. & 50 & 900 & 100 & $1.998 \cdot 10^{-08}$ & 153.985 \\
\hline 9. & 50 & 1200 & 120 & $2.385 .10^{-08}$ & 152.448 \\
\hline 10. & 50 & 1500 & 40 & $1.912 \cdot 10^{-08}$ & 154.370 \\
\hline 11. & 75 & 300 & 80 & $1.653 \cdot 10^{-08}$ & 155.631 \\
\hline 12. & 75 & 600 & 100 & $2.486 \cdot 10^{-08}$ & 152.089 \\
\hline 13. & 75 & 900 & 120 & $1.547 .10^{-08}$ & 156.206 \\
\hline 14. & 75 & 1200 & 40 & $3.601 \cdot 10^{-08}$ & 148.871 \\
\hline 15. & 75 & 1500 & 60 & $2.211 \cdot 10^{-09}$ & 173.108 \\
\hline 16. & 100 & 300 & 100 & $2.658 \cdot 10^{-08}$ & 151.507 \\
\hline 17. & 100 & 600 & 120 & $3.666 \cdot 10^{-08}$ & 148.716 \\
\hline 18. & 100 & 900 & 40 & $2.814 .10^{-08}$ & 151.011 \\
\hline 19. & 100 & 1200 & 60 & $1.485 \cdot 10^{-08}$ & 156.562 \\
\hline 20. & 100 & 1500 & 80 & $2.734 \cdot 10^{-08}$ & 151.263 \\
\hline 21. & 125 & 300 & 120 & $3.318 \cdot 10^{-08}$ & 149.582 \\
\hline 22. & 125 & 600 & 40 & $4.506 \cdot 10^{-08}$ & 146.923 \\
\hline 23. & 125 & 900 & 60 & $3.014 \cdot 10^{-08}$ & 150.415 \\
\hline 24. & 125 & 1200 & 80 & $2.635 \cdot 10^{-08}$ & 151.582 \\
\hline 25. & 125 & 1500 & 100 & $1.897 .10^{-08}$ & 154.438 \\
\hline & & & & & \\
\hline
\end{tabular}

\section{RESULTS AND DISCUSSION}

The applied load, sliding speed and track or interface diameter were chosen as operating parameters, and L25 orthogonal array was used to determine the best operating parameters. Tables 3 and 4 show the results of the statistical analysis of response parameters, as well as the computed ANOVA and $\mathrm{S} / \mathrm{N}$ ratio.

\subsection{Analysis of effect of control factor}

Analysis of the effect of each control factor on the brake pad material wear rate was performed with a $\mathrm{S} / \mathrm{N}$ response table, using a Minitab 18.0 computer package. The experiments were carried out as per the Taguchi method, and the wear rate of the pad material was measured for each combination of all the control factors. The condition "smaller-is-better" was used to calculate signal to noise ratios [15]. For each combination of wear 
rate, Table 2 displays the observed $\mathrm{S} / \mathrm{N}$ ratios. The average wear rate values were calculated as $2.162 \cdot 10^{-08} \mathrm{~m} / \mathrm{s}$ during the end of experimentation. The average $S / \mathrm{N}$ ratio values for wear rate are calculated to be $154.62 \mathrm{~dB}$. The $\mathrm{S} / \mathrm{N}$ ratio table for wear response are shown in Table 3. According to Taguchi, the $\mathrm{S} / \mathrm{N}$ ratio should be as high as possible to achieve optimal operating parameters. The level of $\mathrm{S} / \mathrm{N}$ response and the effect of operating parameters on wear rate are shown in Fig. 3 and Table 3. The optimum level for each control factor was determined based on the highest $\mathrm{S} / \mathrm{N}$ and is displayed in Table 3 as bolded wear rate values. According to this, the factors giving the minimum wear rate were specified as applied load (L1, S/N = 159.6), Sliding speed $(\mathrm{V} 5, \mathrm{~S} / \mathrm{N}=158.5)$ and track diameter (D2, S/N = 158.4). In another way, a minimum pad wear was obtained with applied load $25 \mathrm{~N}$, sliding speed $1500 \mathrm{rpm}$ and track diameter of $60 \mathrm{~mm}$.

Table 3. $\mathrm{S} / \mathrm{N}$ ratio response table for pad wear rate

\begin{tabular}{|c|c|c|c|}
\hline Level & $\begin{array}{c}\text { Applied } \\
\text { Load }\end{array}$ & $\begin{array}{c}\text { Sliding } \\
\text { Speed }\end{array}$ & $\begin{array}{c}\text { Track } \\
\text { Diameter }\end{array}$ \\
\hline 1 & $\mathbf{1 5 9 . 6}$ & 153.3 & 152.0 \\
\hline 2 & 153.9 & 153.2 & $\mathbf{1 5 8 . 4}$ \\
\hline 3 & 157.2 & 155.0 & 155.9 \\
\hline 4 & 151.8 & 153.2 & 153.7 \\
\hline 5 & 150.6 & $\mathbf{1 5 8 . 5}$ & 153.2 \\
\hline Delta & 9.0 & 5.3 & 6.4 \\
\hline Rank & 1 & 3 & 2 \\
\hline
\end{tabular}

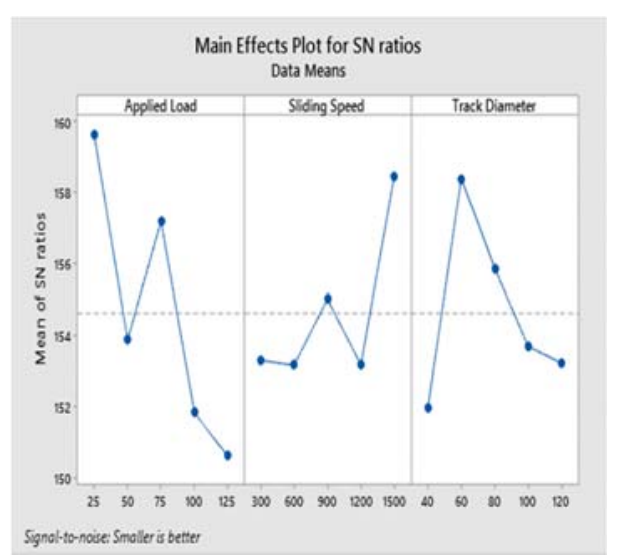

Fig. 3. The influence of operating parameters on wear rate average $\mathrm{S} / \mathrm{N}$ ratios

\subsection{Variance Analysis (ANOVA) for brake pad wear}

Analysis of variance (ANOVA) is a statistical method for determining the impact of various input parameters and for interpreting experimental data.
The effect of applied load, sliding speed, and track diameter on brake pad material wear rate is investigated using ANOVA. This study was performed with a $95 \%$ confidence level and a $5 \%$ significance level. Degrees of freedom, mean square, sum of squares, variance, F-value, P-value and percent of contribution are all included in the ANOVA table.

The significance of each control factor is determined using ANOVA by comparing the $F$ values of each control factor. The greater the $F$ contribution, the greater the impact of a factor on the result. The percentage contribution of each factor to total variation is shown in the last column of the ANOVA table, indicating the degree of impact on the results. The assigned factor is statistically and physically insignificant when ' $F$ ' is less than the ' $5 \%$ ' and error value is greater than the contribution percentage of each factor. Table 4 show the ANOVA results for pad wear rate. The percentage contributions of the applied load $48.07 \%$, sliding speed $19.23 \%$ and track diameter $25 \%$ is found. The applied load (48.07\%) is the most important factor influencing the rate of wear of pad material. The percent of error for wear rate 7.69 is considerably low.

Table 4. Analysis of variance results for pad wear rate

\begin{tabular}{|c|c|c|c|c|c|}
\hline $\begin{array}{l}\bar{\pi} \\
\stackrel{0}{0} \\
\vdash\end{array}$ & के & 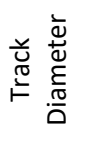 & 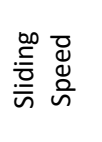 & 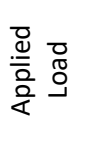 & 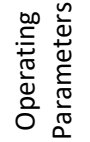 \\
\hline 24 & 12 & 4 & 4 & 4 & DF \\
\hline \multirow[t]{5}{*}{$\begin{array}{c}2.60 \cdot 10^{-} \\
15 \\
\end{array}$} & $\begin{array}{c}2.00 \cdot 10^{-} \\
16\end{array}$ & $\begin{array}{c}6.50 \cdot 10^{-} \\
16\end{array}$ & $5.00 \cdot 10^{-16}$ & $1.25 \cdot 10^{-15}$ & Seq. SS \\
\hline & $\begin{array}{c}1.67 \cdot 10^{-} \\
17\end{array}$ & $\begin{array}{c}1.63 \cdot 10^{-} \\
16\end{array}$ & $1.25 \cdot 10^{-16}$ & $3.13 \cdot 10^{-16}$ & Variance \\
\hline & & 9.8 & 7.5 & 19 & F-Value \\
\hline & & $\begin{array}{c}9.48 \cdot 10^{-} \\
04\end{array}$ & $\begin{array}{c}2.875 \cdot 10^{-} \\
03\end{array}$ & $4.52 \cdot 10^{-04}$ & P-Value \\
\hline & 7.69 & 25 & 19.2 & 48.1 & $\begin{array}{c}\text { Contrib. } \\
(\%)\end{array}$ \\
\hline
\end{tabular}

\subsection{Effect of operating parameters on brake pad wear rate}

The applied load, sliding speed and track diameter are the most important factors that influence pad wear rate. The wear rate values tend to increase as the applied load increases. The metal matrix in friction material becomes unstable as a result of the high applied load, and the asperities dispersed on the contact interface are distorted and fractured, resulting in debris. The wear rate increases at high loads and medium sliding speeds due to the rapid rise in temperature, which causes the pad surface friction material to thermally 
decompose as shown in Fig. 4 (a). For combine effect of applied load and interface diameter the wear rate having non-linear trend because of the wear debris present at the interface was contributed to formation of third body layer or the friction film on friction surface. Friction film produced on the friction surface increases the contact area and strengthened the friction and wear resistance shown in Fig. 4 (b). At low sliding speed and track or interface diameter, the wear rate becomes maximum and slowly decreases with increase in speed and interface area as indicated in Fig. 4 (c). The interface temperature becomes unstable at low speed and track diameters, causing cutting, falling, and deformation of asperities on the contact surface. These asperities are penetrating into the contact surface and causes wear of friction material.

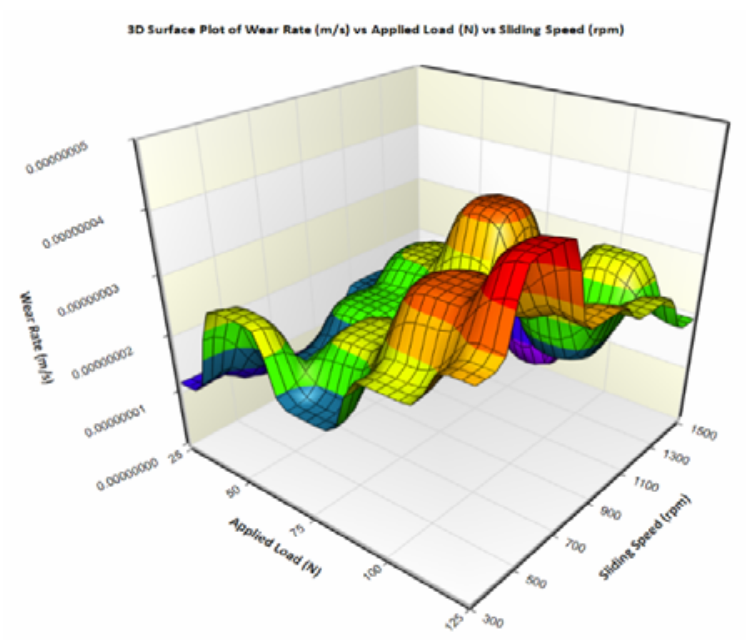

(a)

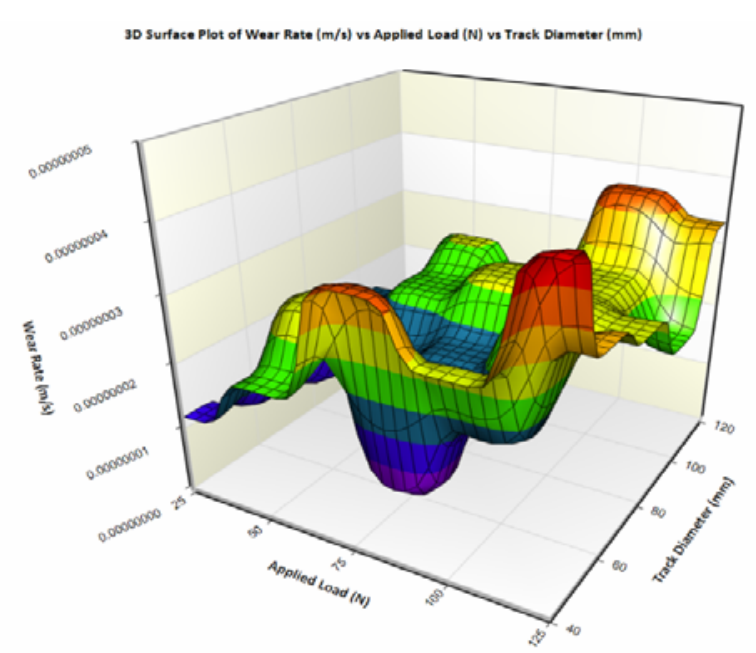

(b)

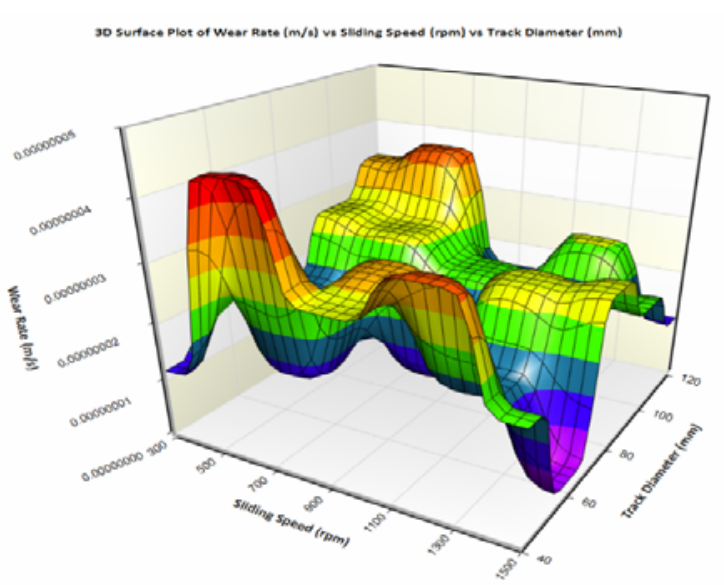

(c)

Fig. 4. Wear rate variation according to different operating parameter combinations: a) applied loadsliding speed, b) applied load-track diameter, c) sliding speed-track dimeter

\subsection{Confirmation experiment}

The final test of the experimental design process is the confirmation experiment. The confirmation experiment's objective is to confirm the findings reached during the analysis phase. The optimized values for the wear rate are calculated from Eq. (3) for L1V5D2 i.e for applied load level 1, sliding speed level 5 and track or interface diameter level 2.

$(\mathrm{W})_{\text {optim. }}=\left(\mathrm{L} 1-\mathrm{W}_{\text {avg }}\right)+\left(\mathrm{V} 5-\mathrm{W}_{\text {avg }}\right)+\left(\mathrm{D} 2-\mathrm{W}_{\mathrm{avg}}\right)+\mathrm{W}_{\mathrm{avg}}(3)$

Where is: (W) optim. - denotes the computed mean of wear rate and $W_{\text {avg }}$ - state the average wear rate determined from the experimental study (Table 2).

As per Equ. (2), it was determined that (W) $)_{\text {optim. }}=$ $6.4846 \cdot 10^{-08} \mathrm{~m} / \mathrm{s}$. The optimised conditions must be analysed in the Taguchi optimization technique. The optimised parameter was evaluated using the confirmation experiment. Table 5 compares the results of the confirmation test with Taguchi's predicted results. The experimental and predicted values are adhering close to each other. For a reliable statistical analysis, the error value should be less than $20 \%$ [15]. The maximum percentage of error computed for wear rate $4.21 \%$, there is within the within permissible limits. The successful optimization is indicated by the test result obtained from the confirmation test. 
Table 5. Comparison of predicted and confirmation test result

\begin{tabular}{|c|c|c|c|}
\hline \multirow{2}{*}{ Test } & \multicolumn{3}{|c|}{ Taguchi Prediction } \\
\cline { 2 - 4 } & $\begin{array}{c}\text { Experimental } \\
\text { wear rate } \\
(\mathrm{m} / \mathrm{s})\end{array}$ & $\begin{array}{c}\text { Predicted } \\
\text { wear rate } \\
(\mathrm{m} / \mathrm{s})\end{array}$ & $\begin{array}{c}\text { Error } \\
(\%)\end{array}$ \\
\hline $\begin{array}{c}\text { L1V5D2 } \\
\text { (Optimum) }\end{array}$ & $6.4846 .10^{-08}$ & $\begin{array}{c}6.3594 .10^{-} \\
08\end{array}$ & 1.93 \\
\hline $\begin{array}{c}\text { L3V4D5 } \\
\text { (Random) }\end{array}$ & $1.453 .10^{-09}$ & $\begin{array}{c}1.3918 .10^{-} \\
09\end{array}$ & 4.21 \\
\hline
\end{tabular}

\section{CONCLUSIONS}

The aim of this study was to analyse the impact of operating parameters on brake pad wear rate and to establish a correlate between wear with these operating parameters. The optimal operating parameters were determined in the brake pad friction material tested against cast iron disc on pin on disc machine under dry conditions by using Taguchi method. The optimal wear rate was validated using confirmation experiments The ANOVA and $\mathrm{S} / \mathrm{N}$ ratio analysis led to the following conclusions:

- According to results of ANOVA investigation, the major contributory parameters affecting the pad material wear rate were applied load with a contribution of $48.07 \%$. The significant contributions of the sliding speed and track or interface diameter on the wear rate were found to be $19.23 \%$ and $25 \%$ respectively.

- The optimum level of operating parameters for wear rate were $25 \mathrm{~N}$ applied load, $1500 \mathrm{rpm}$ sliding speed, and $60 \mathrm{~mm}$ track diameter, on the basis of $\mathrm{S} / \mathrm{N}$ ratio using the "smaller is better" approach.

- Brake pad material wear rate values computed using wear rate equation were highly correlated with experimental values. For wear rate, the maximum percentage of error computed was $4.21 \%$. The measured values were $95 \%$ within the confidence level, according to the confirmation test results.

- With the use of abovementioned optimum conditions brake pad designers can improve the lifecycle.

\section{REFERENCES}

[1] P. Filip, Z. Weiss, D. Rafaja, On friction layer formation in polymer matrix composite materials for brake applications. Wear, 252 (34), 2002: 189-198.

https://doi.org/10.1016/S0043-1648(01)00873-0
[2] S.N. Nagesh, C. Siddaraju, S.V. Prakash, M.R. Ramesh, Characterization of brake pads by variation in composition of friction materials. Procedia Materials Science, 5, 2014: 295-302.

https://doi.org/10.1016/j.mspro.2014.07.270

[3] M. Boz, A. Kurt, Effect of $\mathrm{ZrSiO} 4$ on the friction performance of automotive brake friction materials. Journal of materials science \& technology, 23 (6), 2007: 843-850.

[4] D.S. Chan, G.W. Stachowiak, Review of automotive brake friction materials. Proceedings of the Institution of Mechanical Engineers, Part D: Journal of Automobile Engineering, 218 (9): 2004, 953-66.

https://doi.org/10.1243/0954407041856773

[5] M. Eriksson, S. Jacobson, Tribological surfaces of organic brake pads. Tribology international, 33(12), 2000: 817-27.

https://doi.org/10.1016/\$0301-679X(00)00127-4

[6] G.P. Ostermeyer, M. Müller, Dynamic interaction of friction and surface topography in brake systems. Tribology International, 39 (5), 2006: 370-380.

https://doi.org/10.1016/i.tribo int.2005.04.018

[7] P.C. Verma, L. Menapace, A. Bonfanti, R. Ciudin, S. Gialanella, G. Straffelini, Braking pad-disc system: wear mechanisms and formation of wear fragments. Wear, 322, 2015: 251-258.

https://doi.org/10.1016/j.wear.2014.11.019

[8] N.S. El-Tayeb, K.W. Liew, V.C. Venkatesh, Evaluation of new frictional brake pad materials. InProc. International Conference on Manufacturing Science and Technology, Malacca, Malaysia 2006, 28-30.

[9] H.Y. Lin, H.Z. Cheng, K.J. Lee, C.F. Wang, Y.C. Liu, Y.W. Wang, Effect of Carbonaceous Components on Tribological Properties of Copper-Free NAO Friction Material. Materials, 13(5): 2020, 1163.

https://doi.org/10.3390/ma13051163

[10] J. Bijwe, Composites as friction materials: Recent developments in non-asbestos fiber reinforced friction materials-a review. Polymer composites, 18(3), 1997: 378-396.

https://doi.org/10.1002/pc.10289

[11] X. Xiao, Y. Yin, J. Bao, L. Lu, X. Feng, Review on the friction and wear of brake materials. Advances in Mechanical Engineering, 8(5), 2016: 1-10.

https://doi.org/10.1177/1687814016647300

[12] J.R. Laguna-Camacho, G. Juarez-Morales, C. Calderon-Ramon, V. Velazquez-Martinez, I. Hernandez-Romero, J.V. Mendez-Mendez, M. Vite-Torres, A study of the wear mechanisms of 
disk and shoe brake pads. Engineering Failure Analysis, 56, 2015: 348-359.

https://doi.org/10.1016/i.engfailanal.2015.01.004

[13] B. Zhou, S. Li, Prediction and factor analysis for friction and wear performance of brake disk. Iranian Journal of Science and Technology, Transactions of Mechanical Engineering, 43 (2), 2019: 245-252.

https://doi.org/10.1007/s40997-017-0124-y

[14] M. Federici, S. Gialanella, M. Leonardi, G. Perricone, G. Straffelini, A preliminary investigation on the use of the pin-on-disc test to simulate off-brake friction and wear characteristics of friction materials. Wear, 410 , 2018: 202-9.

https://doi.org/10.1016/i.wear.2018.07.011

[15] P.J. Ross, Taguchi techniques for quality engineering: loss function, orthogonal experiments, parameter and tolerance design. Mcgraw-Hill, 1996.

[16] V.J. Banker, J.M. Mistry, M.R. Thakor, B.H. Upadhyay, Wear behavior in dry sliding of Inconel 600 alloy using Taguchi method and regression analysis. Procedia Technology, 23, 2016: 383-90.

https://doi.org/10.1016/i.protcy.2016.03.041
[17] A. Pattanaik, M.P. Satpathy, S.C. Mishra, Dry sliding wear behavior of epoxy fly ash composite with Taguchi optimization. Engineering Science and Technology, an International Journal, 19(2), 2016: 710-716.

https://doi.org/10.1016/j.jestch.2015.11.010

[18] H. Mehboob, S.H. Chang Optimal design of a functionally graded biodegradable composite bone plate by using the Taguchi method and finite element analysis. Composite Structures, 119, 2015: 166-173.

https://doi.org/10.1016/j.compstruct.2014.08.029

[19] S. Velickovic, B. Stojanovic, M. Babic, I. Bobic, Optimization of tribological properties of aluminum hybrid composites using Taguchi design. Journal of composite materials, 51 (17), 2017: 2505-2515.

https://doi.org/10.1177/0021998316672294

[20] S. Velickovic, B. Stojanovic, M. Babic, A. Vencl, I. Bobic, G.V. Bognar, F. Vucetic, Parametric optimization of the aluminium nanocomposites wear rate. Journal of the Brazilian Society of Mechanical Sciences and Engineering, 41 (19), 2019: 1-10.

https://doi.org/10.1007/s40430-018-1531-8 